\title{
Pathogenesis, Risk Assessment and Prevention of Type 2 Diabetes mellitus
}

\author{
Hans-Georg Joost \\ German Institute of Human Nutrition Potsdam-Rehbrücke, Nuthetal, Germany
}

\section{Keys Words}

Diabetes mellitus - Insulin resistance - Disease risk . Gene variants $\cdot$ Nutrition

\section{Summary}

Type 2 diabetes mellitus is a complex, polygenic disease with a heterogeneous pathophysiology, mainly characterised by obesity-associated insulin resistance and a progressive failure of pancreatic $\beta$-cells. Predominant risk factors for its development are abdominal obesity and age; other factors that augment the individual disease risk independent of obesity are the nutritional pattern (low consumption of fibres, high consumption of red meat, saturated and trans fat), lifestyle (smoking, low physical activity), and biomarkers such as blood pressure, $\mathrm{HbA1c}$, serum adiponectin and inflammatory cytokines. These variables can provide the basis for a precise risk assessment and a personalised prevention. Genotyping for the presently known gene variants conferring an increased disease risk adds relatively little to the information provided by the phenotypic risk factors and biomarkers. However, genetic information is necessary for a personalised risk assessment and intervention that begins before phenotypic risk factors are detectable. The incidence of type 2 diabetes can significantly be lowered by reduction of the intraabdominal fat mass (by nutritional intervention and exercise), and by pharmacological control of post-prandial blood glucose excursions. Because of the high portion of non-responders to a preventive intervention, current efforts aim at the identification of phenotypic and genetic variables predicting the success of the intervention.

\section{Introduction}

Type 2 diabetes represents the most important secondary complication of obesity. As a consequence of the obesity epidemic in industrialised Western countries, we currently observe a steady increase in the incidence of the disease [1]. In Germany, the prevalence of type 2 diabetes is $5-7 \%$, whereas impaired glucose tolerance (IGT, pre-diabetes) can be detected in as much as $10-15 \%$ [2]. On the basis of these data, it has been estimated that the prevalence of diabetes will approach $10 \%$ in Germany in 2010. Moreover, obesity-associated IGT and diabetes is now detected in younger adults, adolescents and even in children that are morbidly obese [3]. Thus, if the current trend continues, type 2 diabetes and its life-shortening secondary complications such as atherosclerosis, coronary heart disease and stroke will constitute a substantial public health problem. The rise in type 2 diabetes has been anticipated to reduce the mean life expectancy [4], and projected to exert detrimental economical consequences for the health care systems $[5,6]$.

Considerable efforts have been made in recent years to find effective preventive measures for a stop or even a reversal of the increase in type 2 diabetes. Ample evidence has been accumulated indicating that a reduction of intraabdominal fat reduces the incidence of the disease [7]. Also, a pharmacological intervention with agents that reduce blood glucose levels, e.g. metformin [8] or the glucosidase inhibitor acarbose [9], reduces the incidence of diabetes in cohorts with impaired glucose tolerance. Thus, type 2 diabetes can be considered a largely preventable disease.

Type 2 diabetes is a complex, polygenic disease with a heterogeneous pathophysiology. It is reasonable to assume, therefore, that a preventive intervention will yield heterogeneous results and that an individualised approach to prevention is preferable. This approach needs guidance by detailed knowledge of the genetic and the pathophysiological basis of the disease and by an individualised risk assessment. Towards this

\begin{tabular}{ll}
\hline KARGER & @ 2008 S. Karger GmbH, Freiburg \\
Fax +49 7614520714 & Accessible online at: \\
$\begin{array}{l}\text { E-mail Information@Karger.de } \\
\text { www.karger.com }\end{array}$ & www.karger.com/ofa
\end{tabular}


Fig. 1. Pathogenesis of insulin resistance and beta cell failure in type 2 diabetes.

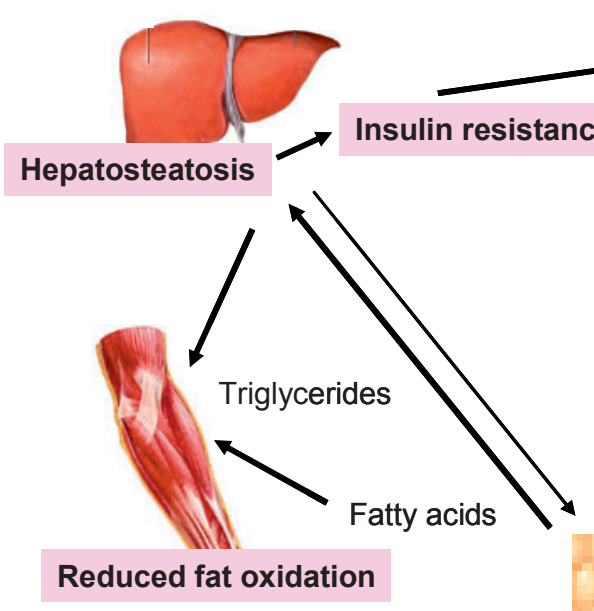

Reduced fat oxidation $\rightarrow$ Hyperglycemia
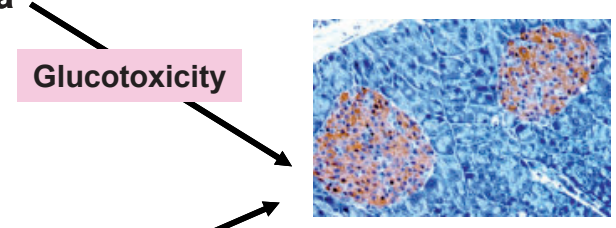

Adiponectin

TNF-alpha IL-6 $\uparrow$

IL-1-beta

Inflammation

ß-cell failure

B-cell failure

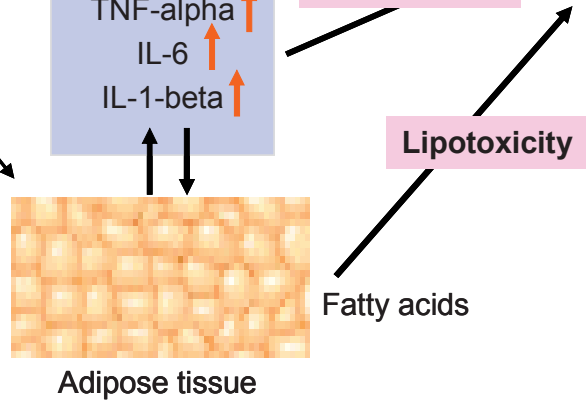

goal, numerous dietary and lifestyle factors have been identified that modify the risk for type 2 diabetes [10]. These factors can be used to precisely determine the individual diabetes risk [11]. This review intends to summarise the current knowledge as to the pathogenesis of obesity-associated type 2 diabetes, its risk assessment and its prevention.

\section{Pathogenesis and Risk Factors of Type 2 Diabetes}

It is generally accepted that type 2 diabetes is caused by the combination of insulin resistance and a progressive failure of pancreatic $\beta$-cells [12]. According to a plausible scenario (fig. 1), insulin resistance occurs when adipose cells reach a critical size and adipose tissue stores become limited. Ectopic triglycerides and fatty acids then produce insulin resistance in liver and muscle. In addition, a chronic inflammatory state, caused by immune cell infiltration into adipose tissue in obesity, appears to contribute to insulin resistance. Ectopic lipids also appear to affect $\beta$-cell function ('lipotoxicity'), probably in combination with the exposure of cells to high glucose concentrations ('glucotoxicity'). This pathogenesis unfolds when a polygenic susceptibility interacts with exogenous factors such as nutrition and physical activity. Therefore, type 2 diabetes is the paradigm of a complex disease which has a genetic basis but is precipitated by exogenous factors [1].

\section{Obesity}

Excess adiposity is considered the most important factor in the pathogenesis of type 2 diabetes. In all mouse models of type 2 diabetes, obesity is essential for the development of hyperglycaemia. In heterogenous outcross populations of the NZO mouse, there is a 'dose-response' relationship between early body weight and the prevalence of later onsetting diabetes [13]. In human type 2 diabetes, the anthropometric para-

meters body weight, body mass index (BMI) and waist circumference are major predictors of the individual disease risk $[10,14,15]$. This risk increase is mainly conferred by the intraabdominal and intrahepatic fat depots [16-18], whereas the subcutaneous fat appears to be indifferent. In mouse models of diabetes and insulin resistance, enhanced hepatic lipogenesis is a key pathophysiological feature $[19,20]$. Intrahepatic triglycerides are believed to cause insulin resistance and are therefore directly linked with the pathophysiology of diabetes; even a small reduction significantly lowers the diabetes risk [21]. In addition, it has been suggested that accumulation of ectopic lipids in other tissues such as muscle and islets is also involved in the pathogenesis of diabetes. Thus, intraabdominal and intrahepatic fat stores might be a marker for the accumulation of triglycerides in $\beta$-cells that was suggested to produce islet cell failure (lipotoxicity, see below).

\section{Mechanism of $\beta$-Cell Failure: Lipotoxicity and Glucotoxicity}

Convincing data have indicated that excess ectopic lipid accumulation is a causal factor in the development of diabetes. In addition, it has been shown that incorporation of excess triglycerides in pancreatic islets can trigger apoptosis of $\beta$-cells [22]. When lipids accumulate in non-adipose tissues during over-nutrition, fatty acids cause the formation of ceramide. Ceramide is a toxic lipid and probably the cause of lipoapoptosis [22]. Alternatively, it has been postulated that elevation of post-prandial and post-absorptive blood glucose levels damage the pancreatic $\beta$-cell (glucotoxicity). According to this hypothesis, the $\beta$-cell is very sensitive to oxidative damage, or is sensitized by a low anti-oxidative capacity [23]. It was suggested that elevated blood glucose concentrations lead to formation of reactive oxygen radicals [24] which cause loss of essential transcription factors such as MafA, and an irreversible cell damage [25]. This hypothesis is supported by numerous experimental findings: Long-term culture of $\beta$-cells in the 
Table 1. Variant genes that were found to be associated with risk of type 2 diabetes $^{\mathrm{a}}$

\begin{tabular}{|c|c|c|}
\hline Gene symbol & Gene function & Identified by \\
\hline CALPN10 & calcium-dependent protease & positional cloning \\
\hline TCF7L2 & transcription factor in Wnt signalling pathway & positional cloning \\
\hline$P P A R G$ & transcription factor in adipocyte differentiation & candidate gene approach \\
\hline KCNJ11 & potassium channel regulating insulin secretion & candidate gene approach \\
\hline$H H E X$ & transcription factor & genome-wide association study \\
\hline SLC $30 A 8$ & zn transporter in insulin-secreting $\beta$-cells & genome-wide association study \\
\hline$C D K A L 1$ & cyclin-dependent kinase associated protein-like 1 & genome-wide association study \\
\hline$C D K N 2$ & cyclin-dependent kinase 2 & genome-wide association study \\
\hline$I G F 2 B P 2$ & insulin-like growth factor binding protein & genome-wide association study \\
\hline FTO & nucleic acid demethylase (?) & genome-wide association study \\
\hline$U B Q L N L$ & ubiquilin 3 & genome-wide association study \\
\hline$R A L G P S 2$ & Ral GTP exchange factor & genome-wide association study \\
\hline EGR2 & early growth response 2 & genome-wide association study \\
\hline WFS1 & calcium homeostasis in ER of $\beta$-cells & candidate gene approach \\
\hline
\end{tabular}

${ }^{a}$ Only associations that were observed in at least 3 different study populations are listed [38-55]. presence of high glucose concentrations affects their function [26]. In $d b / d b[27,28]$ or NZO mice [29], diabetes (defined as histologically assessed $\beta$-cell damage) can be delayed or prevented by feeding a high-protein or high-fat, carbohydratefree diet. Thus, carbohydrates are essential for $\beta$-cell destruction in mouse models of diabetes, and lipotoxicity appears to co-operate with glucotoxicity in this pathogenesis [30].

\section{Role of Adipose Tissue Inflammation and Cytokines}

Obesity is associated with a massive infiltration of adipose tissue with immune cells such as macrophages, and it has been suggested that the pathogenesis of type 2 diabetes has an immunological component in that cytokines released from adipose tissue play a causal role in the insulin resistance and $\beta$ cell failure [31]. Consequently, serum levels of inflammatory cytokines or other biomarkers of inflammatory processes such as IL- 6 and C-reactive protein (CRP) are elevated long before the onset of overt type 2 diabetes [32, 33]. It should be noted, however, that adipose tissue inflammation was fully dissociated from the development of diabetes under a carbohydrate-free diet [29]. Thus, inflammatory cytokines may contribute to the pathogenesis of diabetes, but are not a sufficient factor.

\section{Diabetes Genes}

Obese mouse strains such as the $d b / d b$ (monogenic deletion of the leptin receptor) and the NZO strain (polygenic obesity) develop a type 2 diabetes-like hyperglycaemia that closely resembles the human disease. Their hyperglycaemia is associated with morbid obesity and insulin resistance, and reflects a progressive failure of the pancreatic $\beta$-cells. These models allowed differentiation of adipogenic and diabetogenic (i.e. causing hyperglycaemia) alleles [13, 34, 35]; diabetes requires the presence of both types of predisposing alleles ('diabesity'). Consequently, morbid obesity does not produce diabetes in the absence of diabetogenic alleles (e.g. in the $o b / o b$-mouse or the $f a / f a$-rat). Lean mouse lines (e.g. NON, SJL or C57KS/J) may carry diabetogenic alleles; these will become active only when mice are rendered obese by a single obesity gene (e.g. in the $\mathrm{C} 57 \mathrm{KS} / \mathrm{J}-d b / d b$ strain) or by cross-breeding with a polygenic obesity strain such as NZO [13, 34, 35]. More recently, one of the genes responsible for the diabetogenic effect of the BTBR background, Sorcs1 (encoding sortilin CS1), has been identified [36].

In humans, the genetic contribution to the pathogenesis of type 2 diabetes is equally strong: in identical twins, concordance of type 2 is approximately $80 \%$ for diabetes and even $96 \%$ for impaired glucose tolerance [37]. The genetic contribution is complex, and numerous diabetogenic alleles working in combination appear required for development of the disease [38, 39]. Considerable efforts have been made to identify the genes that cause type 2 diabetes. Table 1 lists a selection of genes that exhibited an association with an altered diabetes risk in at least three different study populations. Three different strategies were employed to identify the diabetogenic variants: Firstly, chromosomal segments (quantitative trait loci, QTL) associated with hyperglycaemia were identified in genome-wide searches, and positional cloning of the gene responsible for the effect of a QTL led to identification of diabetogenic variants of calcium-dependent protease calpain-10 [40] and the transcription factor TCF7L2 [41]. Subsequent investigation of the associations in other cohorts and metaanalysis of the results indicated a robust effect of TCF7L2 (1.5- to 2.5-fold increase in disease risk) that was reproducible in most, but not all studies [42, 43], whereas the effect of the diabetogenic haplotype of calpain-10 was inconsistent and on average only $20 \%$ [44].

Secondly, numerous case control studies identified associations of gene variants by the candidate gene approach (e.g. in $P P A R G$ encoding PPAR $\gamma$ Pro12Ala and in KCNJ11 encoding 
the potassium channel KIR6.2) with an increased diabetes risk. Thirdly, microarray-based, genome-wide association studies identified numerous significant associations of SNPs (single nucleotide polymorphisms) with an elevated disease risk (OR 1.1-1.5) that could be replicated in some, but again not all, other cohorts [46-55]. The contribution of each variant to the overall diabetes risk is small, and numerous associations are therefore not reproducible in other studies. At present, it is not entirely clear whether some of the identified associations represent false-positive results or whether their small effects vary with the populations studied. Furthermore, the functional consequence of these associations is still unclear, and they should therefore be considered loci rather than diabetes genes until direct functional evidence is available. In addition, all so far identified diabetogenic alleles cannot fully explain the genetic susceptibility of diabetes. Thus, it appears reasonable to assume that the major part of the genetic susceptibility has not been elucidated so far. Furthermore, it remains to be investigated whether the effect of the known susceptibility genes depends on nutritional or other environmental parameters, as has been demonstrated in mouse models.

\section{Risk Factors for Type 2 Diabetes: Nutrition and Lifestyle}

Numerous experimental studies in mice as well as observational and intervention studies in humans have investigated the relation between nutritional and lifestyle variables and the risk of type 2 diabetes. It should be noted that detection and analysis of such associations in human cohorts is a difficult task because of several methodological limitations: Firstly, monitoring of nutritional behaviour is based on rather imprecise information gathered by food frequency questionnaires. Secondly, cultural differences between study populations in different countries may give rise to divergent results. Thirdly, the observed associations identify food groups (such as whole grain bread or margarine), and can only suggest chemical entities (fibres or trans fatty acids). Similar and other limitations (e.g. low compliance) apply to intervention studies. In spite of these limitations, human cohort studies provided convincing evidence that nutritional and lifestyle variables are independent risk factors of type 2 diabetes.

\section{Fat}

The effects of macronutrients on the development of diabetes nutrients, in particular that of fat and carbohydrates, have been investigated intensively in rodents and in human studies. In part, these studies have generated divergent results and controversial conclusions. In diabetes-susceptible mouse strains such as NZO, the development of diabetes can be accelerated by a high-fat diet ( $45 \%$ of calories as fat vs. $15 \%$ in a standard diet) [35]. This effect seems to indicate that the $\beta$ cell is sensitive to fatty acids and/or incorporated triglycerides (lipotoxicity). In humans, in contrast, the majority of studies showed little or no effect of the total fat consumption on the diabetes risk that was independent of the body weight. Since the high-fat diet enhances adiposity and insulin resistance in NZO mice as well as in most other mouse strains [56], the diabetogenic effect of a high-fat diet may well be indirect. Several cohort studies that analysed the effects of different triglycerides (saturated, unsaturated and trans fatty acids in triglycerides showed a moderate (approximately 30\%) increase of the diabetes risk by saturated and trans fats, and a similar reduction in individuals with a higher intake of polyunsaturated fats [57]. In conclusion, the ratio of triglycerides consumed (saturated, non-unsaturated, poly-unsaturated and trans-unsaturated fat) rather than their total amount appears to modulate the diabetes risk. In addition, it should be noted that a much larger range of fat consumption was tested in rodents $(15-60 \%$ of total calories) than in humans.

\section{Carbohydrates}

Data from prospective cohort studies have indicated that dietary carbohydrates - independent from the body weight significantly modify the diabetes risk. Consumption of carbohydrates rich in fibres and with a low glycaemic index giving rise to lower post-prandial blood glucose excursions is associated with a reduced diabetes risk $[57,58]$. Conversely, consumption of carbohydrates with a higher glycaemic index increases the risk. In addition, high consumption of sugar-sweetened soft drinks is associated with higher body weight and an elevated diabetes risk [59]. However, some of the effects of carbohydrates were not consistently replicated in other study populations: In the EPIC-Potsdam cohort, the glycaemic load, sweets, or sugar-sweetened soft drinks were not among the factors that significantly modified the diabetes risk (Schulze et al., unpublished). The most consistent effect of carbohydratecontaining foods was the association of cereal fibre consumption with a reduced diabetes risk [60]: this association was replicated in a total of 7 cohorts including EPIC-Potsdam.

Data from mouse models supported the role of dietary carbohydrates in the development of diabetes. Since substitution of protein $[27,28]$ or fat [29] for carbohydrates delayed or prevented the diabetes in $d b / d b$ or NZO mice, respectively, $\beta$-cell destruction in rodent models appears to be dependent on the dietary carbohydrates. These data are consistent with a scenario in which blood glucose excursions, in particular under conditions of insulin resistance and a genetically determined susceptibility of the pancreatic $\beta$-cell, play a crucial role in the pathogenesis of diabetes. Interestingly, the effect of the highfat diet on the development of diabetes can be dependent on certain genotypes. In NZO mice, the effect of a diabetogenic allele on chromosome 5 (tentatively designated Nob1) was dependent on the fat content of the diet, whereas the effect of a second QTL (Nidd/SJL) was not [35]. Such data provide proof of principle for the concept that gene variants may determine the quality of the response to nutrients. Identification of these 
variants in humans will allow the establishment of genotypespecific nutritional recommendations with regard to dietary fat and diabetes risk.

\section{Red Meat}

The quality of meat consumed appears to be a major factor modulating the diabetes risk and might therefore be involved in its pathogenesis. In prospective cohort studies, a significant association between the consumption of red meat (pork, beef and lamb), but not of white meat (poultry) and fish, and the diabetes risk has been observed consistently $[10,11]$. This finding suggests a role of haeme iron in the pathogenesis of diabetes. In the absence of data supporting a molecular link between iron consumption and $\beta$-cell function it can only be speculated that haeme iron catalyses the formation of $\beta$-celltoxic nitroso compounds.

\section{Alcohol}

Moderate alcohol consumption (with the exception of beer) has consistently been observed to lower the diabetes risk [10]. This effect might reflect the inhibitory effect of alcohol on gluconeogenesis and hepatic glucose output which could lead to a reduction of fasting blood glucose levels. In the case of beer, the risk-reducing effect of alcohol seems to be outweighed by its high carbohydrate content [61]. Thus, the effects of alcoholic beverages appear to support a scenario in which blood glucose excursions play a major role in the pathogenesis of $\beta$-cell failure.

\section{Dietary Patterns}

Based on the assumption that dietary effects on disease risk are the result of complex interactions between nutrients, attempts have been made to identify nutritional patterns rather than single nutrients and food components associated with an increased diabetes risk. Van Damm et al. [62] compared a 'prudent' dietary pattern (higher consumption of vegetables, fruit, fish, poultry and whole grains) with a 'western' pattern (higher consumption of red meat, processed meat, French fries, high-fat dairy products, refined grains), and found that the latter was associated with an increased risk (OR 1.6). More recently, a new statistical method, reduced rank regression (RRR), which is similar to the classic principal component analysis but more flexible and powerful, was used to identify dietary patterns associated with diabetes risk [61, 63]. In incident diabetics of the EPIC-Potsdam cohort, dietary patterns were extracted from 49 food groups that explain as much as possible of the response variation of the biomarkers HbA1c, HDL cholesterol, CRP and adiponectin. Thereby, a nutritional pattern was identified consisting of a high consumption of fruits as well as a low consumption of meat, beer, soft drinks and white bread, which was associated with an approximately $80 \%$ reduction of the diabetes risk [61]. A similar risk-reducing nutritional pattern was identified with different methodology in a Finnish cohort [64].

\section{Lifestyle: Physical Activity}

In addition to genetics, anthropometric and nutritional parameters, physical activity is a major factor determining the diabetes risk [65]. Prospective cohort studies indicated that physical activity was significantly lower in diabetics before the onset of their disease than in healthy controls. Men who watched TV for more than $40 \mathrm{~h}$ per week had an approximately 3-fold higher diabetes risk than those who spent less than $1 \mathrm{~h}$ per week watching TV [66]. Furthermore, a protective effect of exercise as part of a weight reduction program including diet was observed in an intervention study [7]. Since the intervention resulted in a minor weight reduction (approximately $4 \mathrm{~kg}$ ) but a substantial $(60 \%)$ reduction of the diabetes risk, the authors suggested that exercise exerted an effect that was independent of the weight reduction. Indeed, after correction for its effect on waist circumference, exercise caused a small but significant reduction of the diabetes risk in the EPIC-Potsdam cohort. This effect may be due to an increased insulin sensitivity of muscle in response to exercise [67].

\section{Lifestyle: Smoking}

The majority of epidemiological studies testing the effect of smoking have detected a moderate increase of the diabetes risk that was reversed after cessation of smoking [10,11]. It is of note that the beneficial effect of smoking cessation apparently outweighs its adverse effect on weight gain. The pathophysiological mechanism of the effect of smoking is unclear. Nicotine stimulates sympathetic nervous activity and may therefore stimulate transient elevations of blood glucose; such an effect would be consistent with the concept that blood sugar excursions play a major role in the pathophysiology of the disease. Indeed, it has previously been shown in a large cohort that smoking is associated with elevated HbA1c levels [68].

\section{Determination of the Risk of Type 2 Diabetes}

The above described risk factors can be used to establish risk scores that can identify individuals at high risk to develop type 2 diabetes, and guide a personalised primary prevention by diet, lifestyle intervention or medication (see below). In addition, such risk scores can be used to compare and match study arms in clinical trials, to assess the efficacy of preventive programs, and to guide decisions as to the intensity of the intervention (lifestyle, pharmacological, surgical intervention). Thus, the precise determination of the diabetes risk is an important tool to reduce diabetes-related morbidity and mortality.

Several requirements for the establishment of a precise diabetes risk score have to be met. Firstly, score values have to be derived from data of incident cases in population-based, prospective cohorts. Secondly, score values assigned to each variable have to be based on a mathematical model, such as the multivariate Cox regression model, allowing determina- 
Table 2. Risk factors for the development of type 2 diabetes as identified in the EPIC Potsdam cohort ${ }^{\mathrm{a}}$

\begin{tabular}{llrr}
\hline Risk factor & Relative risk (95\% CI) & p-value & Score points \\
\hline Waist circumference, cm & $1.076(1.071-1.082)$ & $<0.0001$ & 7.4 \\
Height, cm & $0.976(0.967-0.984)$ & $<0.0001$ & -2.4 \\
Age, years & $1.044(1.035-1.053)$ & $<0.0001$ & 4.3 \\
Hypertension (self report) & $1.587(1.375-1.831)$ & $<0.0001$ & 46 \\
Intake of red meat (each 150 g/day) & $1.639(1.228-2.187)$ & 0.0008 & 49 \\
Intake of whole grain bread (each 50 g/day) & $0.918(0.855-0.986)$ & 0.0193 & -9 \\
Consumption of coffee (each 150 g/day) & $0.958(0.926-0.991)$ & 0.0142 & -4 \\
Alcohol consumption (between 10 and 40 g/day) & $0.821(0.705-0.954)$ & 0.0104 & -20 \\
Sports, biking, gardening, h/week & $0.984(0.973-0.995)$ & 0.0060 & -2 \\
Former smoker & $1.267(1.094-1.469)$ & 0.0016 & 24 \\
Current heavy smoker ( $\geq 20$ cigarettes/day) & $1.901(1.470-2.458)$ & $<0.0001$ & 64 \\
\hline
\end{tabular}

${ }^{a}$ A multivariable Cox regression model was used to determine the independent contributions of each variable [11]. tion of the independent contribution of each risk factor. Thirdly, the resulting score has to be validated in a similar, prospective study population. Finally, the score should be based on variables that can easily be determined, and should provide both high sensitivity and specificity.

\section{Risk Scores Based on Conventional Risk Factors}

Diabetes risk scores have been developed on the basis of data from the San Antonio Heart Study [69], the Finrisk Studies [70], the Japanese American Community Diabetes Study [71], the Atherosclerosis Risk in Communities Study (ARIC) [72], the Rancho Bernardo Study [73] and a population-based survey in Umea, Sweden [74]. These scores meet the above described requirements partially: Only the Finrisk Studies and the ARIC Study exclusively rely on factors to be measured with non-invasive methods, and are therefore inexpensive and applicable outside of clinical practice. The ARIC risk score showed relatively low validity in the testing sample [72]. Furthermore, the Finrisk score has recently been tested in the German Cooperative Health Research in the Region of Augsburg (KORA) Survey 2000 and yielded a low validity to identify undiagnosed cases of diabetes [75], indicating that risk assessments may not necessarily be representative for different countries.

\section{The German Diabetes Risk Score}

Thus, a risk score based on data from the EPIC-Potsdam cohort has been recently been developed (table 2) and validated in a second German cohort in order to meet all requirements [11]. The score has a broad data basis derived from the population-based, prospective EPIC-Potsdam cohort of 25,167 individuals with 849 incident cases of type 2 diabetes, and yielded essentially identical results in a second prospective German cohort of similar size (EPIC-Heidelberg; 23,398 participants, 658 cases). High score values predict future cases of diabetes [11] as well as an unfavourable profile of biomarkers (see below) and can therefore be used to detect pre-diabetes
[76]. The score includes all risk factors that reached statistical significance in the cohort (table 2): age, waist circumference, hypertension, nutritional variables such as consumption of red meat, whole grain bread, coffee and alcohol, physical activity and smoking status. Because of its broad data basis, the German Diabetes Risk Score allows a quantitative assessment of the contribution of each individual risk factor. It is available as an online web tool ( $w w w$.dife.de) as well as a questionnaire.

\section{Biomarkers and Genotypes}

Several serum factors have been identified that may indicate an increased risk of diabetes years before the onset of the disease. Small increases of fasting blood glucose [77] or glycosylated haemoglobin (HbA1c) [78] have been found to be associated with an increased risk to develop overt diabetes. Type 2 diabetes is preceded by a pre-diabetic period in which glucose tolerance is impaired (IGT). Fasting blood glucose is still normal, but increased post-prandial blood glucose excursions are responsible for a small increase in $\mathrm{HbA} 1 \mathrm{c}$ levels. There is a probability of $15-20 \%$ that IGT is converted to fasting hyperglycaemia within the next year. In addition to $\mathrm{HbA1c}$, it has been shown that a moderate elevation of fasting blood glucose levels predicts an increased risk to develop diabetes within a period of 6 years [79].

Serum parameters reflecting insulin resistance such a characteristic alterations of the lipoprotein profile (low HDL cholesterol, elevated triglycerides), markers of hepatosteatosis (e.g. $\gamma$-glutamyltransferase) [80], markers of an inflammatory response such as hs-CRP [61] or elevated levels of cytokines [81], and reduced levels of adiponectin $[82,83]$ are associated with an increased diabetes risk. So far, none of these serum factors have been included in a weighted risk assessment. Thus, it appears possible that the precision of the currently available risk scores can be enhanced further by inclusion of biomarkers.

Numerous gene variants associated with an elevated diabetes risk have so far been identified by positional cloning, case con- 
trol studies of candidates, or in genome-wide association studies (see above). When assessed in more than one study population, the contribution of each variant to the overall diabetes risk was usually small (10-40\% risk increase) and sometimes not reproducible in other studies. Thus, assessment of the diabetes risk with genotypes of several gene variants yields an only 3- to 4-fold increase in the diabetes risk. This is disappointingly low compared with the predictive value of phenotypic parameters such as the weight circumference. Furthermore, the genotypes do not increase the precision of a risk assessment based on phenotypic variables (Schulze et al., unpublished). Thus, routine genotyping for assessment of the diabetes risk cannot be recommended at present. It may, however, once the full genetic contribution has been elucidated, allow an earlier assessment of a person's risk than the phenotypic variables and biomarkers.

\section{Prevention of Type 2 Diabetes}

Convincing evidence indicates that type 2 diabetes is a preventable disease. Randomised clinical trials indicated that weight reduction either by a diet and exercise [7], drug therapy [84] or bariatric surgery [85] significantly reduces the conversion of impaired glucose tolerance to overt type 2 diabetes. Furthermore, blood glucose control by oral antidiabetics $[8,9]$ is similarly effective. In view of the life-shortening and costly secondary complications of the disease, it appears mandatory to intervene as early and as effectively as possible. However, the majority of individuals at risk do not satisfactorily respond to a lifestyle intervention. Thus, intensified intervention such as drug therapy or bariatric surgery may be indicated, provided that the benefit of the intervention outweighs potential negative effects. At present, there are no guidelines as to a pharmacological therapy to reduce the diabetes risk [86]. Also, the decision as to the surgical therapy of obesity (gastric banding, gastric bypass) is currently based on the severity of the obesity rather than on the risk of secondary complications. Thus, assessment of the individual diabetes risk could provide a rational basis for any decision as to intervene by drug or surgical therapy.

Weight control aiming at a reduction of intraabdominal fat mass is the most efficient intervention to reduce the diabetes risk. In addition, several other variables such as physical activity, food choice (both independent of the waist circumference) and smoking have been observed to be associated with the diabetes risk. It should be noted that these associations are based on very solid evidence from prospective studies, but causality has not been established so far by controlled intervention studies. It may be impossible to obtain the required evidence in randomised controlled studies with the endpoint diabetes mellitus for some of the variables (e.g. red meat consumption, dietary fibres); surrogate markers, intermediate outcome and/or pathobiochemical evidence may therefore represent the best proof of causality obtainable. For example, substitution of saturated for mono-unsaturated fat reduced insulin sensitivity in the short intervention study KANWU [87]. In the opinion of these authors, recommendations for the prevention of diabetes should include modifiable risk factors even in the absence of controlled intervention studies. With regard to dietary recommendations for the prevention of type 2 diabetes, it appears reasonable to advocate a 'healthy diet' rich in cereal fibres, with a reduced amount of red meat and with a reduced amount of saturated and trans fats. In the case of smoking, causality is very likely because previous smokers had a significantly lower diabetes risk than current smokers [11]. Also, causality of the effect of hypertension on the diabetes risk is supported by the risk-reducing effect of the ACE inhibitor ramipril $[88,89]$. Consequently, the normalisation of blood pressure should be included in the recommendations for the prevention of diabetes.

\section{Future Developments}

Type 2 diabetes has a highly heterogeneous pathophysiological basis with a complex interaction of obesity, insulin resistance and $\beta$-cell failure. Thus, it is not surprising that the response to preventive measures is highly heterogeneous. Indeed, this response can be predicted from phenotypic variables such as the visceral fat mass [90]. It is reasonable to assume, therefore, that there are individuals with particular sensitivity towards a risk factor like inactivity, whereas in others the nutritional variables play a dominating role for the diabetes risk. Identification of such subtypes and of factors predicting the heterogeneous response to an intervention could advance the personalisation of the diabetes prevention. Future research will also show whether genotypes can be used as biomarkers predicting not only diabetes risk but also the response to preventive measures. There is already preliminary evidence that the presence or absence of certain diabetogenic alleles can predict the success of an intervention [91, 92]. However, the presently available genetic information is not sufficient for a precise assessment of the response to lifestyle or dietary intervention. Thus, identification of the full genetic basis of type 2 diabetes, and of its interaction with exogenous variables, will be required to establish a personalised intervention.

\section{References}

1 Diamond J: The double puzzle of diabetes. Nature 2003;423:599-602.

2 Hanefeld M, Kohler C: Screening, prevention and early therapy of type 2 diabetics MMW Fortschr Med 2004;146:28-31.
3 Wabitsch M, Hauner H, Hertrampf M, Muche R, Hay B, Mayer H, Kratzer W, Debatin KM, Heinze E: Type II diabetes mellitus and impaired glucose regulation in Caucasian children and adolescents with obesity living in Germany. Int J Obes Relat Metab Disord 2004;28:307-313.
4 Manuel DG, Schultz SE: Health-related quality of life and health-adjusted life expectancy of people with diabetes in Ontario, Canada, 1996-1997. Diabetes Care 2004;27:407-414.

5 Wolf AM, Colditz GA: Current estimates of the economic cost of obesity in the United States. Obes Res 1998;6:97-106. 
6 Hauner H, Landgraf R, Schulze J, Spranger J, Standl E: Nationales Aktionsforum Diabetes mellitus. Prävention des Typ-2-Diabetes mellitus. Positionspapier des Nationalen Aktionsforum Diabetes Mellitus. Dtsch Med Wochenschr 2005;130:10531054

7 Tuomilehto J, Lindstrom J, Eriksson JG, Valle TT, Hamalainen H, Ilanne-Parikka P, KeinanenKiukaanniemi S, Laakso M, Louheranta A, Rastas M, Salminen V, Uusitupa M; Finnish Diabetes Prevention Study Group: Prevention of type 2 diabetes mellitus by changes in lifestyle among subjects with impaired glucose tolerance. $\mathrm{N}$ Engl J Med 2001;344:1343-1350.

-8 Knowler WC, Barrett-Connor E, Fowler SE, Hamman RF, Lachin JM, Walker EA, Nathan DM; Diabetes Prevention Program Research Group: reduction in the incidence of type 2 diabetes with lifestyle intervention or metformin. N Engl J Med 2002;346:393-403.

9 Chiasson JL, Josse RG, Gomis R, Hanefeld M, Karasik A, Laakso M; STOP-NIDDM Trial Research Group: acarbose for prevention of type 2 diabetes mellitus: the STOP-NIDDM randomised trial. Lancet 2002;359:2072-2077.

10 Schulze MB, Hu FB: Primary prevention of diabetes: what can be done and how much can be prevented? Annu Rev Public Health 2005;26:445-467.

11. Schulze MB, Hoffmann K, Boeing H, Linseisen J, Rohrmann S, Möhlig M, Pfeiffer AF, Spranger J, Thamer C, Häring HU, Fritsche A, Joost HG: An accurate risk score based on anthropometric, dietary, and lifestyle factors to predict the development of type 2 diabetes. Diabetes Care 2007;30: 510-515.

12 Kahn BB: Type-2-diabetes: when insulin secretion fails to compensate for insulin resistance. Cell 1998;92:593-596.

13 Plum L, Kluge R, Giesen K, Altmuller J, Ortlepp JR, Joost HG: Type 2 diabetes-like hyperglycaemia in a backcross model of NZO and SJL mice: characterization of a susceptibility locus on chromosome 4 and its relation with obesity. Diabetes 2000; 49:1590-1596.

14 Colditz GA, Willett WC, Rotnitzky A, Manson JE: Weight gain as a risk factor for clinical diabetes mellitus in women. Ann Intern Med 1995;122:481486.

15 Wang Y, Rimm EB, Stampfer MJ, Willett WC, Hu FB: Comparison of abdominal adiposity and overall obesity in predicting risk of type 2 diabetes among men. Am J Clin Nutr 2005;81:555-563.

16 Bajaj M, Suraamornkul S, Piper P, Hardies LJ, Glass L, Cersosimo E, Pratipanawatr T, Miyazaki Y, DeFronzo RA: Decreased plasma adiponectin concentrations are closely related to hepatic fat content and hepatic insulin resistance in pioglitazone-treated type 2 diabetic patients. J Clin Endocrinol Metab 2004;89:200-206.

17 Bajaj M, Suraamornkul S, Pratipanawatr T, Hardies LJ, Pratipanawatr W, Glass L, Cersosimo E, Miyazaki Y, DeFronzo RA: Pioglitazone reduces hepatic fat content and augments splanchnic glucose uptake in patients with type 2 diabetes. Diabetes 2003;52:1364-1370.

18 Stumvoll M: Control of glycaemia: from molecules to men. Minkowski Lecture 2003. Diabetologia 2004;47:770-781.

19 Lan H, Rabaglia ME, Stoehr JP, Nadler ST, Schueler KL, Zou F, Yandell BS, Attie AD: Gene expression profiles of nondiabetic and diabetic obese mice suggest a role of hepatic lipogenic capacity in diabetes susceptibility. Diabetes 2003;52: 688-700.
20 Becker W, Kluge R, Kantner T, Linnartz K, Korn M, Tschank G, Plum L, Giesen K, Joost HG: Differential hepatic gene expression in a polygenic mouse model with insulin resistance and hyperglycaemia: Evidence for a combined transcriptional dysregulation of gluconeogenesis and fatty acid synthesis. J Mol Endocrinol 2004:32:195-208.

21 Petersen KF, Dufour S, Befroy D, Lehrke M, Hendler RE, Shulman GI: Reversal of nonalcoholic hepatic steatosis, hepatic insulin resistance, and hyperglycaemia by moderate weight reduction in patients with type 2 diabetes. Diabetes 2005;54:603-608.

22 Unger RH: Weapons of lean body mass destruction: the role of ectopic lipids in the metabolic syndrome. Endocrinology 2003;144:5159-5165.

23 Leahy JL: Natural history of beta-cell dysfunction in NIDDM. Diabetes Care 1990;13:992-1010.

24 Brownlee M: A radical explanation for glucoseinduced beta cell dysfunction. J Clin Invest 2003; 112:1788-1790.

25 Harmon JS, Stein R, Robertson RP: Oxidative stress-mediated, post-translational loss of MafA protein as a contributing mechanism to loss of insulin gene expression in glucotoxic beta cells. J Biol Chem 2005;280:11107-11113.

26 Robertson RP, Zhang HJ, Pyzdrowski KL, Walseth TF: Preservation of insulin mRNA levels and insulin secretion in HIT cells by avoidance of chronic exposure to high glucose concentrations. J Clin Invest 1992;90:320-325.

27 Leiter EH, Coleman DL, Eisenstein AB, Strack I: Dietary control of pathogenesis in C57BL/KsJ db/db diabetes mice. Metabolism 1981;30:554-562.

28 Leiter EH, Coleman DL, Ingram DK, Reynolds MA: Influence of dietary carbohydrate on the induction of diabetes in C57BL/KsJ-db/db diabetes mice. J Nutr 1983;113:184-195

29 Jürgens H, Schmolz K, Neschen S, Ortmann S, Blüher M, Klaus S, Tschöp M, Joost HG, Schürmann A: Development of diabetes in morbidly obese New-Zealand Obese (NZO) mice requires dietary carbohydrates: Evidence for an essential role of glucose toxicity in $\beta$-cell destruction. Diabetologia 2006;50:1481-1489.

30 Poitout V, Robertson RP: Minireview: Secondary beta-cell failure in type 2 diabetes - a convergence of glucotoxicity and lipotoxicity. Endocrinology 2002;143:339-342.

32 Spranger J, Kroke A, Möhlig M, Bergmann MM, Ristow M, Boeing H, Pfeiffer AF: Adiponectin and protection against type 2 diabetes mellitus. Lancet 2003;361:226-228.

31 Kolb H, Mandrup-Poulsen T: An immune origin of type 2 diabetes? Diabetologia 2005;48:1038-1050.

33 Sjoholm A, Nystrom T: Inflammation and the etiology of type 2 diabetes. Diabetes Metab Res Rev 2006;22:4-10.

34 Leiter EH, Reifsnyder PC, Flurkey K, Partke HJ, Junger E, Herberg L: NIDDM genes in mice: deleterious synergism by both parental genomes contributes to diabetogenic thresholds. Diabetes 1998; 47:1287-1295.

35 Plum L, Giesen K, Kluge R, Junger E, Linnartz K, Schurmann A, Becker W, Joost HG: Characterisation of the mouse diabetes susceptibilty locus Nidd/SJL: islet cell destruction, interaction with the obesity QTL Nob1, and effect of dietary fat. Diabetologia 2002;45:823-830.

36 Clee SM, Yandell BS, Schueler KM, Rabaglia ME, Richards OC, Raines SM, Kabara EA, Klass DM, Mui ET, Stapleton DS, Gray-Keller MP, Young MB, Stoehr JP, Lan H, Boronenkov I, Raess PW, Flowers MT, Attie AD: Positional cloning of Sorcs1, a type 2 diabetes quantitative trait locus. Nat Genet 2006;38:688-693.
77 Medici F, Hawa M, Ianari A, Pyke DA, Leslie RD. Concordance rate for type II diabetes mellitus in monozygotic twins: actuarial analysis. Diabetologia 1999;42:146-150.

38 Hansen L, Pedersen O: Genetics of type 2 diabetes mellitus: status and perspectives. Diabetes Obesity Metab 2005;7:122-135.

39 Stevenson C, Barroso I, Wareham N: The genetics of type 2 diabetes; in Brigelius-Flohé R, Joost HG (eds): Nutritional Genomics. Weinheim, WileyVCH, 2006, pp 223-265.

40 Horikawa Y, Oda N, Cox NJ, Li X, Orho-Melander M, Hara M, Hinokio Y, Lindner TH, Mashima H, Schwarz PE, del Bosque-Plata L, Horikawa Y, Oda Y, Yoshiuchi I, Colilla S, Polonsky KS, Wei S, Concannon P, Iwasaki N, Schulze J, Baier LJ, Bogardus C, Groop L, Boerwinkle E, Hanis CL, Bell GI: Genetic variation in the gene encoding calpain-10 is associated with type 2 diabetes mellitus. Nat Genet 2000;26:163-175.

41 Grant SF, Thorleifsson G, Reynisdottir I, Benediktsson R, Manolescu A, Sainz J, Helgason A, Stefansson H, Emilsson V, Helgadottir A, Styrkarsdottir U, Magnusson KP, Walters GB, Palsdottir E, Jonsdottir T, Gudmundsdottir T, Gylfason A Saemundsdottir J, Wilensky RL, Reilly MP, Rader DJ, Bagger Y, Christiansen C, Gudnason V, Sigurdsson G, Thorsteinsdottir U, Gulcher JR, Kong A, Stefansson K: Variant of transcription factor 7-like 2 (TCF7L2) gene confers risk of type 2 diabetes. Nat Genet 2006;38:320-323.

42 Cauchi S, El Achhab Y, Choquet H, Dina C, Krempler F, Weitgasser R, Nejjari C, Patsch W, Chikri M, Meyre D, Froguel P: TCF7L2 is reproducibly associated with type 2 diabetes in various ethnic groups: a global meta-analysis. J Mol Med 2007;85:777-782.

43 Guo T, Hanson RL, Traurig M, Muller YL, Ma L, Mack J, Kobes S, Knowler WC, Bogardus C, Baier LJ: TCF7L2 is not a major susceptibility gene for type 2 diabetes in Pima Indians: analysis of 3,501 individuals. Diabetes 2007;56:3082-3088.

44 Song Y, Niu T, Manson JE, Kwiatkowski DJ, Liu S: Are variants in the CAPN10 gene related to risk of type 2 diabetes? A quantitative assessment of population and family-based association studies. Am J Hum Genet 2004;74:208-222.

45 Barroso I, Luan J, Middelberg RP, Harding AH, Franks PW, Jakes RW, Clayton D, Schafer AJ, O'Rahilly S, Wareham NJ: Candidate gene association study in type 2 diabetes indicates a role for genes involved in beta-cell function as well as insulin action. PLoS Biol 2003;1:E20.

46 Sladek R, Rocheleau G, Rung J, Dina C, Shen L, Serre D, Boutin P, Vincent D, Belisle A, Hadjadj S, Balkau B, Heude B, Charpentier G, Hudson TJ, Montpetit A, Pshezhetsky AV, Prentki M, Posner BI, Balding DJ, Meyre D, Polychronakos C, Froguel P: A genome-wide association study identifies novel risk loci for type 2 diabetes. Nature 2007;445: 881-885.

47 Scott LJ, Mohlke KL, Bonnycastle LL, Willer CJ, Li Y, Duren WL, Erdos MR, Stringham HM, Chines PS, Jackson AU, Prokunina-Olsson L, Ding CJ, Swift AJ, Narisu N, Hu T, Pruim R, Xiao R, Li XY, Conneely KN, Riebow NL, Sprau AG, Tong M, White PP, Hetrick KN, Barnhart MW, Bark CW, Goldstein JL, Watkins L, Xiang F, Saramies J, Buchanan TA, Watanabe RM, Valle TT, Kinnunen L, Abecasis GR, Pugh EW, Doheny KF, Bergman RN, Tuomilehto J, Collins FS, Boehnke M: A genome-wide association study of type 2 diabetes in Finns detects multiple susceptibility variants. Science 2007;316:1341-1345. 
48 Steinthorsdottir V, Thorleifsson G, Reynisdottir I, Benediktsson R, Jonsdottir T, Walters GB, Styrkarsdottir U, Gretarsdottir S, Emilsson V, Ghosh S, Baker A, Snorradottir S, Bjarnason H, Ng MC, Hansen T, Bagger Y, Wilensky RL, Reilly MP, Adeyemo A, Chen Y, Zhou J, Gudnason V, Chen G, Huang H, Lashley K, Doumatey A, So WY, Ma RC, Andersen G, Borch-Johnsen K, Jorgensen T, van Vliet-Ostaptchouk JV, Hofker MH, Wijmenga C, Christiansen C, Rader DJ, Rotimi C, Gurney M, Chan JC, Pedersen O, Sigurdsson G, Gulcher JR, Thorsteinsdottir U, Kong A, Stefansson K: A variant in CDKAL1 influences insulin response and risk of type 2 diabetes. Nat Genet 2007;39:770-775.

49 Saxena R, Voight BF, Lyssenko V, Burtt NP, de Bakker PI, Chen H, Roix JJ, Kathiresan S, Hirschhorn JN, Daly MJ, Hughes TE, Groop L, Altshuler D, Almgren P, Florez JC, Meyer J, Ardlie K, Bengtsson Boström K, Isomaa B, Lettre G, Lind blad U, Lyon HN, Melander O, Newton-Cheh C, Nilsson P, Orho-Melander M, Råstam L, Speliotes EK, Taskinen MR, Tuomi T, Guiducci C, Berglund A, Carlson J, Gianniny L, Hackett R, Hall L, Holmkvist J, Laurila E, Sjögren M, Sterner M, Surti A, Svensson M, Svensson M, Tewhey R, Blumenstiel B, Parkin M, Defelice M, Barry R, Brodeur W, Camarata J, Chia N, Fava M, Gibbons J, Handsaker B, Healy C, Nguyen K, Gates C, Sougnez C, Gage D, Nizzari M, Gabriel SB, Chirn GW, Ma Q, Parikh H, Richardson D, Ricke D, Purcell S: Genome-wide association analysis identifies loci for type 2 diabetes and triglyceride levels. Science 2007;316: 1331-1336.

50 Sandhu MS, Weedon MN, Fawcett KA, Wasson J, Debenham SL, Daly A, Lango H, Frayling TM, Neumann RJ, Sherva R, Blech I, Pharoah PD, Palmer CN, Kimber C, Tavendale R, Morris AD, McCarthy MI, Walker M, Hitman G, Glaser B, Permutt MA, Hattersley AT, Wareham NJ, Barroso I: Common variants in WFS1 confer risk of type 2 diabetes. Nat Genet 2007:39:951-953.

51 Florez JC, Manning AK, Dupuis J, McAteer J, Irenze K, Gianniny L, Mirel DB, Fox CS, Cupples LA, Meigs JB: A 100K genome-wide association scan for diabetes and related traits in the Framingham Heart Study: replication and integration with other genome-wide datasets. Diabetes 2007;56:3063-3074.

52 Hanson RL, Bogardus C, Duggan D, Kobes S, Knowlton M, Infante AM, Marovich L, Benitez D, Baier LJ, Knowler WC: A search for variants associated with young-onset type 2 diabetes in American Indians in a $100 \mathrm{~K}$ genotyping array. Diabetes 2007;56:3045-3052.

53 Aulchenko YS, Pullen J, Kloosterman WP, Yazdanpanah M, Hofman A, Vaessen N, Snijders PJ, Zubakov D, Mackay I, Olavesen M, Sidhu B, Smith VE, Carey A, Berezikov E, Uitterlinden AG, Plasterk RH, Oostra BA, van Duijn CM: LPIN2 is associated with type 2 diabetes, glucose metabolism, and body composition. Diabetes 2007;56:3020-3026.

54 Rampersaud E, Damcott CM, Fu M, Shen H, McArdle P, Shi X, Shelton J, Yin J, Chang YP, Ott SH, Zhang L, Zhao Y, Mitchell BD, O'Connell J, Shuldiner AR: Identification of novel candidate genes for type 2 diabetes from a genome-wide association scan in the Old Order Amish: evidence for replication from diabetes-related quantitative traits and from independent populations. Diabetes 2007; 56:3053-3062.

55 Hayes MG, Pluzhnikov A, Miyake K, Sun Y, Ng MC, Roe CA, Below JE, Nicolae RI, Konkashbaev A, Bell GI, Cox NJ, Hanis CL: Identification of type 2 diabetes genes in Mexican Americans through genome-wide association studies. Diabetes 2007;56: 3033-3044.
56 West DB, Boozer CN, Moody DL, Atkinson RL: Dietary obesity in nine inbred mouse strains. Am J Physiol 1992;262:R1025-1032.

$57 \mathrm{Hu}$ FB, Manson JE, Stampfer MJ, Colditz G, Liu S, Solomon CG, Willett WC: Diet, lifestyle, and the risk of type 2 diabetes mellitus in women. $\mathrm{N}$ Engl $\mathrm{J}$ Med 2001;345:790-797.

58 Willett W, Manson J, Liu S: Glycemic index, glycemic load, and risk of type 2 diabetes. Am J Clin Nutr 2002;76:274S-280S.

59 Schulze MB, Manson JE, Ludwig DS, Colditz GA, Stampfer MJ, Willett WC, Hu FB: Sugar-sweetened beverages, weight gain, and incidence of type 2 diabetes in young and middle-aged women. JAMA 2004;292:927-934.

60 Schulze MB, Schulz M, Heidemann C, Schienkiewitz A, Hoffmann K, Boeing H: Fiber and magnesium intake and incidence of type 2 diabetes: a prospective study and meta-analysis. Arch Intern Med 2007;167:956-965.

61 Heidemann C, Hoffmann K, Spranger J, KlipsteinGrobusch K, Mohlig M, Pfeiffer AF, Boeing H: A dietary pattern protective against type 2 diabetes in the European Prospective Investigation into Cancer and Nutrition (EPIC)-Potsdam Study cohort. Diabetologia 2005;48:1126-1134.

62 van Dam RM, Rimm EB, Willett WC, Stampfer MJ, Hu FB: Dietary patterns and risk for type 2 diabetes mellitus in U.S. men. Ann Intern Med 2002; 136:201-209.

63 Hoffmann K, Schulze MB, Schienkiewitz A, Nothlings $\mathrm{U}$, Boeing H: Application of a new statistical method to derive dietary patterns in nutritional epidemiology. Am J Epidemiol 2004;159:935-944.

64 Montonen J, Knekt P, Harkanen T, Jarvinen R, Heliovaara M, Aromaa A, Reunanen A: Dietary patterns and the incidence of type 2 diabetes. Am J Epidemiol 2005;161:219-227.

65 Sigal RJ, Kenny GP, Wasserman DH, CastanedaSceppa C: Physical activity/exercise and type 2 diabetes. Diabetes Care 2004:27:2518-2539.

$66 \mathrm{Hu}$ FB, Leitzmann MF, Stampfer MJ, Colditz GA, Willett WC, Rimm EB: Physical activity and television watching in relation to risk for type 2 diabetes mellitus in men. Arch Intern Med. 2001;161:15421548.

67 Hawley JA: Exercise as a therapeutic intervention for the prevention and treatment of insulin resistance. Diabetes Metab Res Rev 2004;20:383-393.

68 Sargeant LA, Khaw KT, Bingham S, Day NE, Luben RN, Oakes S, Welch A, Wareham NJ: Cigarette smoking and glycaemia: the EPIC-Norfolk Study. European Prospective Investigation into Cancer. Int J Epidemiol 2001;30:547-554.

69 Stern MP, Williams K, Haffner SM: Identification of persons at high risk for type 2 diabetes mellitus: do we need the oral glucose tolerance test? Ann Intern Med 2002;136:575-581.

70 Lindstrom J, Tuomilehto J: The diabetes risk score: a practical tool to predict type 2 diabetes risk. Diabetes Care 2003;26:725-731.

71 McNeely MJ, Boyko EJ, Leonetti DL, Kahn SE, Fujimoto WY: Comparison of a clinical model, the oral glucose tolerance test, and fasting glucose for prediction of type 2 diabetes risk in Japanese Americans. Diabetes Care 2003;26:758-763.

72 Schmidt MI, Duncan BB, Bang H, Pankow JS, Ballantyne CM, Golden SH, Folsom AR, Chambless LE: Identifying individuals at high risk for diabetes: the Atherosclerosis Risk in Communities study. Diabetes Care 2005;28:2013-2018.
73 Kanaya AM, Fyr CL, de Rekeneire N, Shorr RI, Schwartz AV, Goodpaster BH, Newman AB, Harris T, Barrett-Connor E: Predicting the development of diabetes in older adults: the derivation and validation of a prediction rule. Diabetes Care 2005;28: 404-408.

74 Norberg M, Eriksson JW, Lindahl B, Andersson C Rolandsson O, Stenlund H, Weinehall L: A combination of $\mathrm{HbA} 1 \mathrm{c}$, fasting glucose and BMI is effective in screening for individuals at risk of future type 2 diabetes: OGTT is not needed. J Intern Med 2006;260:263-271.

75 Rathmann W, Martin S, Haastert B, Icks A, Holle R, Lowel H, Giani G; KORA Study Group: Performance of screening questionnaires and risk scores for undiagnosed diabetes: the KORA Survey 2000. Arch Intern Med 2005;165:436-441.

76 Schulze MB, Boeing H, Fritsche A, Häring HU, Joost HG: Validation of the German Diabetes Risk Score (DRS) with metabolic risk factors for type 2 diabetes (in German). Dtsch Med Wochenschr 2008; 133: 878-883.

77 Tirosh A, Shai I, Tekes-Manova D, Israeli E, Pereg D, Shochat T, Kochba I, Rudich A; Israeli Diabetes Research Group: Normal fasting plasma glucose levels and type 2 diabetes in young men. $\mathrm{N}$ Engl J Med 2005;353:1454-1462.

78 Khaw KT, Wareham N, Luben R, Bingham S, Oakes S, Welch A, Day N: Glycated haemoglobin, diabetes, and mortality in men in Norfolk cohort of european prospective investigation of cancer and nutrition (EPIC-Norfolk) BMJ 2001;322:15-18.

79 Lyssenko V, Almgren P, Anevski D, Perfekt R, Lahti K, Nissen M, Isomaa B, Forsen B, Homstrom N, Saloranta C, Taskinen MR, Groop L, Tuomi T; Botnia study group: Predictors of and longitudinal changes in insulin sensitivity and secretion preceding onset of type 2 diabetes. Diabetes 2005;54: 166-174.

80 Perry IJ, Wannamethee SG, Shaper AG: Prospective study of serum gamma-glutamyltransferase and risk of NIDDM. Diabetes Care 1998;21:732737.

81 Herder C, Baumert J, Thorand B, Koenig W, de Jager W, Meisinger C, Illig T, Martin S, Kolb H Chemokines as risk factors for type 2 diabetes: results from the MONICA/KORA Augsburg study, 1984-2002. Diabetologia 2006;49:921-929.

82 Spranger J, Kroke A, Mohlig M, Hoffmann K, Bergmann MM, Ristow M, Boeing H, Pfeiffer AF: Inflammatory cytokines and the risk to develop type 2 diabetes: results of the prospective population-based European Prospective Investigation into Cancer and Nutrition (EPIC)-Potsdam Study. Diabetes 2003;52:812-817.

83 Trujillo ME, Scherer PE: Adiponectin - journey from an adipocyte secretory protein to biomarker of the metabolic syndrome. J Intern Med 2005;257: 167-175.

84 Torgerson JS, Hauptman J, Boldrin MN, Sjostrom $\mathrm{L}$ : XENical in the prevention of diabetes in obese subjects (XENDOS) study: a randomized study of orlistat as an adjunct to lifestyle changes for the prevention of type 2 diabetes in obese patients. Diabetes Care 2004;27:155-161.

85 Sugerman HJ, Wolfe LG, Sica DA, Clore JN: Diabetes and hypertension in severe obesity and effects of gastric bypass-induced weight loss. Ann Surg 2003;237:751-756

86 Costa A, Conget I, Gomis R: Impaired glucose tolerance: is there a case for pharmacologic intervention? Treat Endocrinol 2002;1:205-210. 
87 Vessby B, Unsitupa M, Hermansen K, Riccardi G Rivellese AA, Tapsell LC, Nälsén C, Berglund L, Louheranta A, Rasmussen BM, Calvert GD, Maffetone A, Pedersen E, Gustafsson IB, Storlien LH; KANWU Study: Substituting dietary saturated for monounsaturated fat impairs insulin sensitivity in healthy men and women: The KANWU Study. Diabetologia 2001;44:312-319.
88 Yusuf S, Gerstein H, Hoogwerf B, Pogue J, Bosch J, Wolffenbuttel BH, Zinman B; HOPE Study Investigators: Ramipril and the development of diabetes. JAMA 2001;286:1882-1885.

89 Scheen AJ: Prevention of type 2 diabetes mellitus through inhibition of the renin-angiotensin system. Drugs 2004:64:2537-2565.

90 Thamer C, Machann J, Stefan N, Haap M, Schäfer S, Brenner S, Kantartzis K, Claussen C, Schick F, Haring $\mathrm{H}$, Fritsche A: High visceral fat mass and high liver fat are associated with resistance to lifestyle intervention. Obesity 2007;15:531-538.
91 Weyrich P, Stefan N, Häring HU, Laakso M, Fritsche A: Effect of genotype on success of lifestyle intervention in subjects at risk for type 2 diabetes. J Mol Med 2007;85:107-117.

92 Fisher E, Boeing H, Hoffmann K, Fritsche A, Doering F, Joost HG, Schulze MB: Whole-grain bread consumption and TCF7L2 rs7903146: Gene-environment interaction in modulating type 2 diabetes risk. Br J Nutr 2008; (in press). 